\title{
ПОНЯТТЯ ОХОРОННИХ АДМІНІСТРАТИВНО-ПРАВОВИХ ГАРАНТІЙ ЗАКОННОСТІ ДІЯЛЬНОСТІ ЩОДО ЗАБЕЗПЕЧЕННЯ ЕКОНОМІЧНИХ ІНТЕРЕСІВ УКРАЇНИ
}

\author{
THE CONCEPT OF SECURITY ADMINISTRATIVE AND LEGAL GUARANTEES \\ OF LEGALITY OF ACTIVITIES TO ENSURE THE ECONOMIC INTERESTS OF UKRAINE
}

\author{
Лавренюк Ю.Ф., к.н. $з$ держ. упр., докторант \\ Національний університет «Одеська юридична академія»
}

\begin{abstract}
Статтю присвячено визначенню поняття охоронних адміністративно-правових гарантій законності діяльності щодо забезпечення економічних інтересів України, визначенню на цій основі перспективних напрямів подальших досліджень цього явища, а також напрямів удосконалення чинного адміністративного законодавства.

Визначено, що охоронні адміністративно-правові гарантії законності діяльності щодо забезпечення економічних інтересів України $€$ системою передбачених охоронними нормами адміністративного права адміністративно-правових засобів та заходів, спрямованих на підтримання та забезпечення режиму законності в діяльності суб'єктів забезпечення економічних інтересів України, насамперед посадових осіб органів державної влади та місцевого самоврядування. У складі таких гарантій виділено матеріальні (підстави та заходи адміністративної відповідальності) і процедурні (адміністративні процедурні механізми їх застосування). Обґрунтовано доцільність розгляду вказаних гарантій у широкому (як матеріальні, так і процедурні засоби забезпечення законності розглядуваної діяльності) та вузькому (окремо або матеріальний, або процедурний контекст) сенсі.

Доведено, що охоронні гарантії законності в досліджуваній ссрері мають неоднаковий зміст залежно від правової природи суб'єкта адміністративного правовідношення, щодо якого вони застосовуються. Так, у разі вчинення адміністративного правопорушення посадовою особою органу державної влади або місцевого самоврядування суб'єкт розгляду відповідної справи про адміністративне правопорушення під час здійснення його правової оцінки має виходити із засад правової законності, що передбачає хоча й правовий характер закону, але орієнтується передусім на ті правові норми, що закріплені позитивно. У випадках же притягнення до адміністративної відповідальності приватних суб'єктів (фізична особа чи приватна юридична особа) мають реалізовуватись засади верховенства права щодо оцінки їхньої діяльності в разі вчинення конкретного правопорушення.

Обґрунтовано, що положення про гуманізацію адміністративної відповідальності приватних суб'єктів зумовлюють перспективність розрізнення в КУПАП посадових осіб «публічного права» та посадових осіб приватних юридичних осіб із встановленням щодо перших жорсткіших санкцій, ніж щодо других.

Ключові слова: охоронні норми, регулятивні норми, гарантії законності, способи забезпечення законності, економічні інтереси,
\end{abstract} державний інтерес, публічне адміністрування.

The article is devoted to the definition of the concept of protective administrative and legal guarantees of legality of activities to ensure the economic interests of Ukraine, the definition on this basis of promising areas of further research on this phenomenon, as well as - areas of improvement of current administrative legislation.

It is determined that protective administrative and legal guarantees of legality of activity on ensuring economic interests of Ukraine are a system of administrative legal means and measures provided by protective norms of administrative law aimed at maintaining and ensuring legality in activity of subjects of ensuring economic interests of Ukraine, first of all officials state power and local self-government. Such guarantees include material (grounds and measures of administrative liability) and procedural (administrative procedural mechanisms of their application). The expediency of consideration of the specified guarantees in a wide (both material, and procedural means of maintenance of legality of the considered activity) and narrow (separately or material, or procedural context) is substantiated.

It is proved that the protective guarantees of legality in the research area have different meanings depending on the legal nature of the subject of the administrative legal relationship to which they are applied. Thus, in the case of an administrative offense by an official of a public authority or local government, the subject of the relevant case on an administrative offense in its legal assessment must proceed from the principles of legal legality, which provides although the legal nature of the law, but focuses primarily on those legal norms that are enshrined positively. In cases of bringing to administrative responsibility of private entities (natural person or private legal entity) the principles of the rule of law should be implemented in assessing their activities in committing a specific offense.

It is substantiated that the provisions on the humanization of administrative liability of private entities determine the prospects of distinguishing in the Code of Administrative Offenses of officials of «public law» and officials of private legal entities, with the establishment of the former tougher sanctions than the latter.

Key words: security norms, regulatory norms, guarantees of legality, ways of ensuring legality, economic interests, state interest, public administration

Роль охоронних адміністративно-правових гарантій законності діяльності щодо забезпечення економічних інтересів України (насамперед адміністративної відповідальності та адміністративних процедурних механізмів ïx застосування) розкривається в положеннях сучасних наукових досліджень щодо ролі адміністративної відповідальності в забезпеченні законності публічного адміністрування загалом. Так, В.А. Крижановська відзначає забезпечувальну функцію адміністративної відповідальності стосовно належного втілення правових приписів як у правореалізації, так і у правозастосуванні [1, с. 11-12]. Із такою позицією варто погодитися. Втім, сьогоднішня криза публічного адміністрування у сфері економіки значною мірою зумовлена невідповідністю системи вказаних гарантій актуальному суспільному запиту, що виявилось, з одного боку, в тенденціях посилення юридичної, зокрема кримінальної, відповідальності суб'єктів правовідносин у сфері економіки, а з іншого - у констатації в програмних документах необхідності вдосконалення гарантій законності діяльності суб'єктів державної влади у сфері економіки. Але при цьому, попри наведене, практично не приділено увагу розвитку адміністративно-правових охоронних гарантій законності вказаної діяльності, а зосереджено на таких регулятивних механізмах, як: судова влада, правоохоронні органи, антикорупційна діяльність [2, с. 28]. Впливовою причиною цього вважаємо недостатність теоретичного опрацювання проблематики досліджуваних гарантій, зокрема вироблення їх єдиного поняття як підгрунтя для подальшого вдосконалення їх застосування як системного адміністративно-правового явища.

Проблематика поняття охоронних адміністративноправових гарантій законності діяльності щодо забезпечення економічних інтересів України не дістала належної уваги в науковій літературі. Зокрема, найбільш дотичними 
варто вважати дослідження з проблематики: загального поняття адміністративно-правових гарантій законності та його застосування в окремих сферах адміністративної діяльності (О.П. Нагорний, 2003 р.; О.В. Солдатова, 2010 р.); поняття адміністративної відповідальності посадових осіб (В. Белінгіо, 2016 р.; К.Л. Бугайчук, 2016 р.; С.С. Засунько, 2015 р.; В.А. Крижановська, 2016 р.); адміністративних процедурних механізмів іiі застосування (Є.О. Пилипенко, 2015 р.; О.П. Рябченко, 2020 р.; В.В. Хомутянський, 2020 р.).

Тому актуальним є визначення поняття охоронних адміністративно-правових гарантій законності діяльності щодо забезпечення економічних інтересів України, визначення на цій основі перспективних напрямів подальших досліджень цього явища, а також напрямів удосконалення чинного адміністративного законодавства.

У доктрині теорії права охоронна функція права пов'язана 3 охороною (захистом) належного існування та розвитку суспільних відносин. Охоронними гарантіями законності у зв'язку з цим можна вважати певні правові явища, закріплені в охоронних нормах: підстави юридичної відповідальності та заходи іiі застосування [3, с. 96]. Наукові дослідження у сфері адміністративного права наслідують цей підхід. Так, охоронними гарантіями законності правоохоронної та управлінської діяльності у сфері оподаткування визначається, зокрема, юридична відповідальність приватних та посадових осіб у вказаній сфері. Втім, галузевий характер вказаних напрацювань дозволяє авторам виділяти і процедурний аспект указаних гарантій, що виявляється передусім у виділенні правових процедур розгляду правових спорів [4, с. 258-259]. Загалом, підтримуючи виділення процедурного контексту розглядуваних гарантій, варто зазначити про певну спірність таких позицій, адже вони не узгоджуються з наведеними вище напрацюваннями 3 теорії права. Крім того, хоча розгляд відповідних спорів і має певне охоронне значення, його безпосередньою метою $є$ внесення правової визначеності в конкретну спірну ситуацію, але не здійснення охоронної функції. 3 іншого боку, виділення процедурного аспекту окреслених гарантій уявляється необхідним 3 огляду на визнаний у теорії права взаємозв'язок норм матеріального права як засобів закріплення певних прав та обов'язків i норм процесуального права як таких, що відображають засоби їх реалізації [3, с. 164]. Тому в процедурному контексті варто виділяти адміністративно-правові механізми реалізації адміністративно-правової відповідальності суб'єктів забезпечення економічних інтересів України. У матеріальному ж контексті охоронними гарантіями діяльності зазначених суб'єктів виступають підстави та заходи адміністративної відповідальності. При цьому варто виділяти широкий (як матеріальні, так і процедурні засоби забезпечення законності розглядуваної діяльності) та вузький зміст указаних гарантій (може розглядатись окремо або матеріальний, або процедурний контекст).

Окреслені положення уможливлюють установлення співвідношення досліджуваних гарантій та родового щодо них поняття, що виділяється окремими вченими в теорії адміністративного права: адміністративно-правові гарантії законності, що досліджуються в контексті окремих сфер адміністративно-правових відносин, зокрема в адміністративній діяльності міліції. Порівняльний аналіз наведених категорій дає підстави для виділення таких ознак вказаних гарантій, як: обов'язковий нормативний характер; є результатом правотворчості уповноважених суб'єктів; тісний зв'язок із позаправовими гарантіями законності (політичні, економічні, ідеологічні, соціальні); комплексна спрямованість, оскільки об'єктом є законність поведінки обох суб'єктів правовідношення; $€$ цілісною системою, що складається з підсистем; кінцевою метою $\epsilon$ належна реалізація матеріальних норм адміністративного права [5, с. $849 ; 6$, с. 31-32].
Попри поширеність участі в економічних відносинах приватних осіб (громадян), вирішальне значення для реалізації державних інтересів у цій сфері має діяльність публічних осіб: уповноважених посадових осіб органів державної влади та уповноважених посадових осіб підприємств, установ, організацій. Характер охоронних гарантій (реалізація юридичної відповідальності) в поєднанні з гуманістичною спрямованістю сучасного розвитку публічного адміністрування свідчить про можливість доповнення вказаних ознак. Додатковою ознакою досліджуваних гарантій постає мінімізація використання вказаних гарантій стосовно приватних осіб - учасників адміністративних правовідносин - щодо забезпечення економічних інтересів України та зосередження їхньої сфери дії щодо забезпечення законності діяльності суб'єктів публічної влади у сфері економіки, а також посадових осіб суб'єктів господарювання.

Окреслена специфіка досліджуваних гарантій надає можливість звернути увагу на інші їхні істотні особливості як правової категорії. Визначення основним суб'єктом адміністративної відповідальності публічних осіб зумовлює неможливість застосування до оцінки їхніх діянь положень принципу верховенства права, оскільки вони діють виключно на виконання своїх завдань та в межах своїх повноважень. Тому суб'єкти розгляду відповідних адміністративних справ мають виходити із засад правової законності, що передбачає хоча й правовий характер закону, але виходить передусім із тих правових норм, що закріплені позитивно [7, с. 489]. У випадках же притягнення до адміністративної відповідальності приватних суб'єктів, наприклад, як це передбачено ст. 42-1 Кодексу України про адміністративні правопорушення від 07.12.1984 р. № 8073-Х (далі - КУПАП) [8] (виробництво, заготівля, реалізація сільськогосподарської продукції, що містить хімічні препарати понад гранично допустимі рівні концентрації), мають реалізовуватись засади верховенства права щодо оцінки їхньої діяльності в разі вчинення конкретного правопорушення. Тому охоронні гарантії законності в досліджуваній сфері мають неоднаковий зміст залежно від правової природи суб'єкта адміністративного правовідношення, щодо якого вони застосовуються.

Неоднаковий характер правових режимів діяльності публічних і приватних осіб як учасників відповідних адміністративних правовідносин не означає, що досліджувані гарантії не можуть розглядатись як цілісна система. Адже як загальнодозвільний правовий режим (ч. 1 ст. 19 Конституції України від 28.06.1996 р. № 254к/96-ВР (далі - Конституція України) [9]), так і спеціальний (ч. 2 ст. 19 Конституції України), охоплюються категорією законності, а окреслені відмінності зумовлені особливістю правового положення людини порівняно з публічними суб' єктами.

У філософській літературі виділяються такі ознаки системи як об'єкта дослідження за системним підходом: цілісність (об'єкт штучно розділений для вивчення, але органічно складає єдине ціле), примат цілого над частинами (ціле не зводиться до сукупності частин), ієрархічність (наявність у складі системи елементів та підсистем різного рівня, що ієрархічно пов'язані між собою), полісистемність (у складі досліджуваної системи можливо виокремити кілька підсистем) [10, с. 584]. Цілісність досліджуваних гарантій як системи зумовлюється не тільки єдиною метою їх застосування (забезпечення законності діяльності відповідних суб'єктів), не тільки специфічною сферою (публічне адміністрування у сфері економіки), але й специфічними методами такого адміністрування, що передбачають переважну роль планувальної діяльності та видання актів стратегічного, рамкового характеру [11, с. 340-343]. Взаємопов'язаність економічних процесів зумовлює пріоритет цілого над частинами, оскільки неможливо забезпечити законність у цій сфері, реалізовуючи лише окремі гарантії та не реалізовуючи інші. 
Висновок щодо ієрархічного та полісистемного характеру розглядуваних гарантій слідує з можливості виділення комплексних гарантій (наприклад, провадження у справі про адміністративне правопорушення) та їхніх окремих елементів, що теж складають систему (наприклад, конкретна стадія провадження у справі про адміністративне правопорушення).

Цілісний, системний характер охоронних гарантій законності діяльності щодо забезпечення економічних інтересів України в поєднанні з положеннями про перспективну сферу їх застосування (відповідальність посадових осіб саме державної влади) свідчить про необхідність уточнення викладених у нормах КУпАП положень щодо визначення посадової особи як суб'єкта адміністративної відповідальності. Наприклад, у ст. 42 КУпАП (порушення санітарних норм) суб'єктом адміністративного правопорушення визначається, зокрема, «посадова особа». При цьому не уточнюється: посадова особа суб'єкта державної влади чи посадова особа приватної юридичної особи. 3 огляду на висловлювану в юридичній літературі позицію щодо єдиного розуміння терміна «Посадова особа» у КУПАП [12, с. 65] слідує висновок про однакове застосування санкції цієї статті як до першої, так і до другої посадової особи. Втім, окреслені положення про гуманізацію адміністративної відповідальності приватних суб'єктів зумовлюють перспективність розрізнення в КУПАП посадових осіб «публічного права» та посадових осіб приватних юридичних осіб із встановленням щодо перших посадових осіб більших санкцій, ніж щодо других. Реалізація такої пропозиції потребує значної роботи, оскільки зумовлює необхідність внесення змін також до ст. 14 КУпАП (відповідальність посадових осіб) у контексті їх розмежування.

Отже, охоронні адміністративно-правові гарантії законності діяльності щодо забезпечення економічних інтересів України є системою передбачених охоронними нормами адміністративного права адміністративно-правових засобів та заходів, спрямованих на підтримання та забезпечення режиму законності в діяльності суб'єктів забезпечення економічних інтересів України, насамперед посадових осіб органів державної влади та місцевого самоврядування. У складі таких гарантій варто розрізняти матеріальні (підстави та заходи адміністративної відповідальності) та процедурні (адміністративні процедурні механізми їх застосування). Вказані гарантії можуть розглядатись у широкому (як матеріальні, так і процедурні засоби забезпечення законності розглядуваної діяльності) та вузькому (окремо або матеріальний, або процедурний контекст) сенсі.

Охоронні гарантії законності в досліджуваній сфері мають неоднаковий зміст залежно від правової природи суб'єкта адміністративного правовідношення, щодо якого вони застосовуються. Так, у разі вчинення адміністративного правопорушення посадовою особою органу державної влади або місцевого самоврядування суб'єкт розгляду відповідної справи про адміністративне правопорушення під час здійснення його правової оцінки має виходити із засад правової законності, що передбачає хоча й правовий характер закону, але орієнтується передусім на ті правові норми, що закріплені позитивно. У випадках же притягнення до адміністративної відповідальності приватних суб'єктів (фізична особа чи приватна юридична особа) мають реалізовуватись засади верховенства права щодо оцінки їхньої діяльності в разі вчинення конкретного правопорушення. Визначення сутності, функціональної спрямованості, а також ознак досліджуваних гарантій створює підстави щодо їх подальшої систематизації.

Положення про гуманізацію адміністративної відповідальності приватних суб'єктів зумовлюють перспективність розрізнення в КУпАП посадових осіб «публічного права» та посадових осіб приватних юридичних осіб із встановленням щодо перших жорсткіших санкцій, ніж щодо других.

\section{ЛITEPATУРA}

1. Крижановська В.А. Адміністративна відповідальність в адміністративному праві України: сучасне розуміння, нові підходи : автореф. дис. ... канд. юрид. наук : 12.00.07. Львів, 2016. 19 с.

2. Національна економічна стратегія 2030. Вектори економічного розвитку. Національна економічна стратегія 2030 : веб-сайт. URL: https://nes2030.org.ua/\#rec245890384 (дата звернення: 21.01.2021).

3. Теорія держави і права / за ред. О.В. Петришина. Харків : Право, 2015. 368 с.

4. Правове регулювання управлінської та правоохоронної діяльності у сфері оподаткування : монографрія / за ред. О.П. Рябченко. Харків : Панов, 2016. 472 с.

5. Солдатова О.В. Сутність та загальна характеристика юридичних гарантій законності в адміністративній діяльності ОВС України. Форум права. 2010. № 4. C. 846-852. URL: http://nbuv.gov.ua/j-pdf/FP_index.htm_2010_4_136.pdf (дата звернення: 04.02.21).

6. Нагорний О.П. Законність в адміністративній діяльності органів внутрішніх справ та шляхи ї̈ удосконалення : дис. ... канд. юрид. наук : 12.00 .07 ; Національна академія внутрішніх справ України. Київ, 2003. 205 с.

7. Скакун О.Ф. Теорія права і держави : підручник. Київ : Алерта; КНТ; ЦУЛ, 2010. 520 с.

8. Кодекс України про адміністративні правопорушення від 07.12.1984 р. № 8073-Х. Відомості Верховної Ради УРСР. Від 18.12 .1984$. № 51. Ст. 1122 (із змінами).

9. Конституція України від 28.06.1996р. № 254к/96-ВР. Відомості Верховної Ради України. Від 23.07.1996. № 30. Ст. 141 (із змінами).

10. Філософський енциклопедичний словник / редкол. : В.І. Шинкарук (голова) та ін. Київ : Абрис, 2002. 742 с.

11. Адміністративне право України. Повний курс : підручник / В. Галунько та ін. Херсон : ОЛДІ-ПЛЮС, 2018. 446 с.

12. Засунько С.С., Плаз О.М., Волосовський В.В. Сутність та підстави адміністративної відповідальності посадових осіб як суб'єктів адміністративного правопорушення. Науковий вісник Міжнародного гуманітарного університету. Серія: Юриспруденція. 2015. № 18. Том. 1. С. 63-66. 